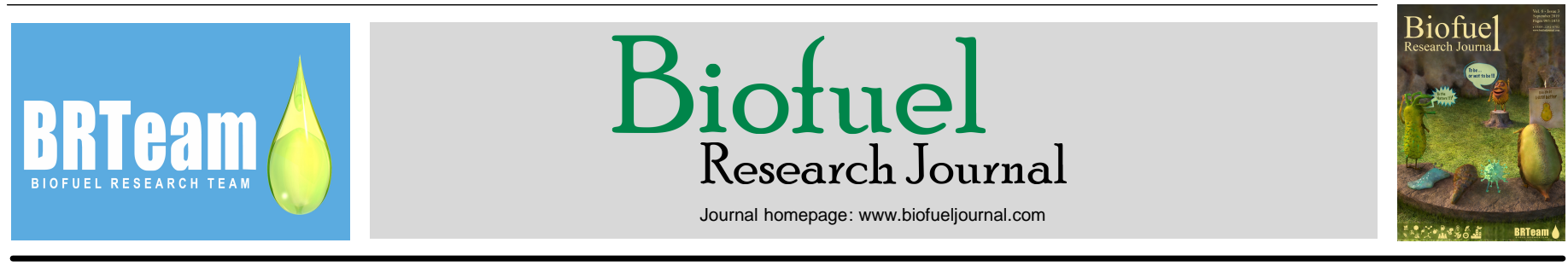

Original Research Paper

\title{
An integrated approach to explore UASB reactors for energy recycling in pulp and paper industry: a case study in Brazil
}

Samuel Fontenelle Ferreira ${ }^{1}$, Luz Selene Buller ${ }^{1}$, Mauro Donizeti Berni ${ }^{2}$, Sergio Valdir Bajay ${ }^{2}$, Tânia Forster-Carneiro ${ }^{1, *}$

${ }^{1}$ Faculty of Food Engineering, University of Campinas (UNICAMP), Rua Monteiro Lobato, 80, 13083-862, Campinas, São Paulo, Brazil.

${ }^{2}$ Interdisciplinary Center of Energy Planning (NIPE), University of Campinas (UNICAMP), Rua Cora Coralina, 13083-970, Campinas, São Paulo, Brazil.

\section{HIGHLIGHTS}

$>$ Conceptual 'systemic' biorefinery framework for simultaneous wastewater treatment and bioenergy/biomaterail recovery was developed. $>$ UASB reactor-based biorefinery was found efficient in addressing the environmental concerns faced by the pulp and paper industry.

$>$ Investment required for UASB reactors would be minor accounting for only $6.8 \%$ of the mill`s annual sales.

$>$ Nationwide implementation of the proposed biorefinery could avoid national GHG emissions by $1.06 \times 10^{5} \mathrm{CO}_{2 \mathrm{eq}}$ tons.

$>$ Biogas burning in stationary engines can avoid USD 2.89 Millions in electric energy charge.

\section{GRAPHICAL ABSTRACT}

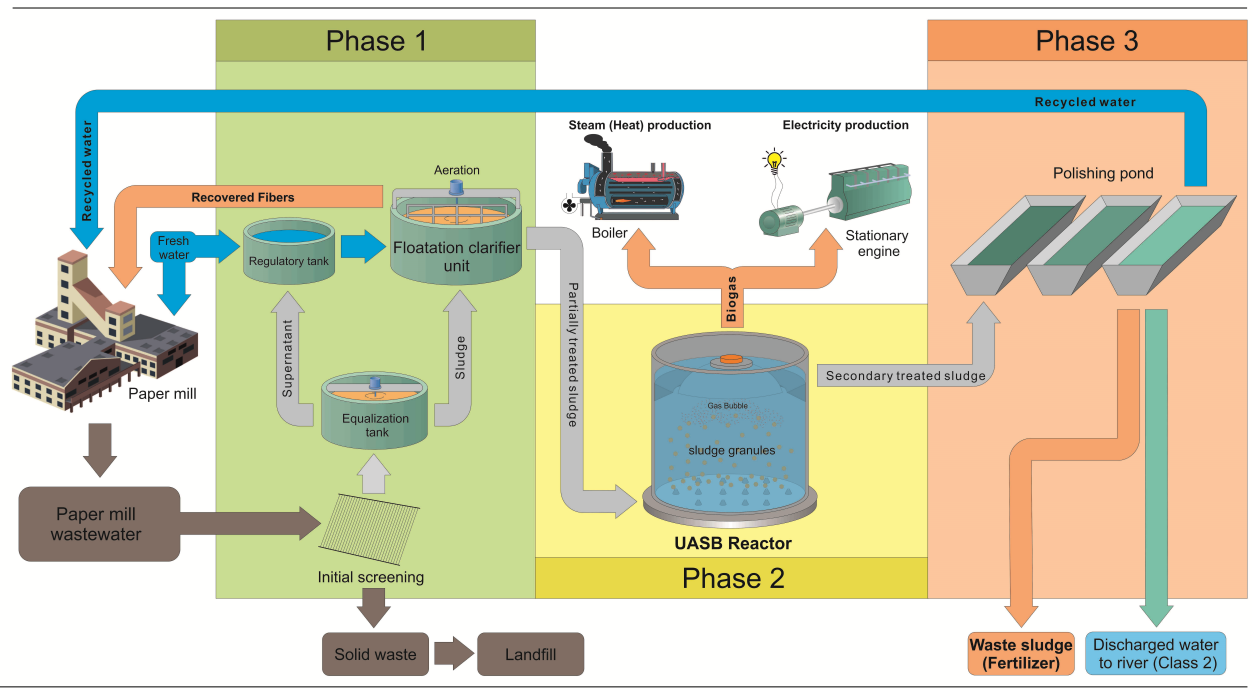

\begin{abstract}
Brazil is currently focused on its energy matrix transition in favor of increasing of the share of renewable energy carriers for both enhanced energy security and mitigation of greenhouse gas emissions. In this context, the country`s pulp and paper industry whose different wastes teams are not generally exploited, could play a critical role. Accordingly, the main objective of this work is to develop a conceptual 'systemic' biorefinery framework integrating the treatment of pulp and paper mill wastewater using upflow anaerobic sludge blanket (UASB) reactor with energy recovery through biogas production and its conversion into heat and power in stationary engines and boilers, respectively. Based on the results obtained through the present case study, it was revealed that the adoption of UASB reactors by the paper mill industry could properly addresses the environmental concerns faced while could contribute to the national agenda favoring an increasing share of renewable energies in the country`s energy matrix. The financial analysis showed that the investment required for the implementation of UASB reactors within a biorefinery platform would be minor $v s$. the investment in the whole mill and would be returned in $6.4 \mathrm{yr}$ with a high return on investment even when operated at half of operational capacity. Moreover, through the developed UASB reactor-based biorefinery, the Brazilian pulp and paper industry as a whole could avoid $1.06 \times 10^{5} \mathrm{CO}_{2 \text { eq }}$ tons, effectively contributing to the decarbonization of the country`s economy.
\end{abstract}

(c) 2019 BRTeam. All rights reserved.

* Corresponding author at: Tel.: +55 1935214041

E-mail address: taniafc@unicamp.br

Please cite this article as: Ferreira S.F., Buller L.S., Berni M.D., Bajay S.V., Forster-Carneiro T. An integrated approach to explore a UASB reactor for pulp and paper industry energy recycling: case study in Brazil. Biofuel Research Journal 23 (2019) 1039-1045. DOI: 10.18331/BRJ2019.6.3.4 


\section{Introduction}

Bioenergy produced from biological resources and different biomasses, rich in carbon structures, including wood and agricultural wastes can be exploited for the production of heat, electricity, or fuels, contributing to the global decarbonization. In the developing countries, the large scale adoption of energy recycling strategies for several industrial wastewaters and residues is still a challenge when compared to the developed countries which have already embraced technological solutions to properly deal with byproducts, i.e., side products derived from the processing of the main products and wastes (dos Santos et al., 2018). Energy matrix transition in the developing countries such as Brazil, lacks an effective strategy to valorize wastewaters and residues through energy recycling while there is a huge dependence on fossil fuels (57\% of the total domestic energy supply) as well as on hydro and thermoelectric energies $(65.2 \%$ and $27.8 \%$ of the domestic electricity supply including renewable and non-renewable sources, respectively) (EPE, 2018). Meanwhile, there are great opportunities for biomass-to-energy scenarios from several resources in Brazil (Welfle, 2017).

Brazilian efforts to increase the production and use of renewable energy carriers were strongly accelerated after the $21^{\text {st }}$ Conference of the Parties to the United Nations Framework Convention on Climate Change (COP 21) and after the establishment of RenovaBio - a state policy that aims to draw up a joint strategy to recognize the strategic role of all types of bioenergies in the Brazilian energy matrix, both for energy security and for mitigation of greenhouse gas (GHG) emissions purposes (MME, 2018a). At the COP 21, Brazil committed to reduce its GHG emissions to $37 \%$ and $43 \%$ less than its 2005 baseline by 2025 and 2030, respectively (MMA, 2018).

The challenge extends to the Brazilian wood-based industry, including pulp and paper production, which is locally important and contributes more than $6 \%$ of the National Industrial Gross Domestic Product (IBÁ, 2017). In this industry, wastewater sludge, produced in high quantities, is difficult to handle because of its high water content (55 to 85\%) and low dewaterability properties (Foekel, 2010; Bayr, 2014; Berni et al., 2014). Pulp and paper mill wastewater usually contains inks, dyes, very high levels of biochemical oxygen demand (BOD) (20 to $40 \mathrm{mg} / \mathrm{L}$ ) and chemical oxygen demand (COD) (300 to $500 \mathrm{mg} / \mathrm{L}$ ) due to the presence of lignin and its derivatives, chlorinated compounds, suspended solids (mainly fibers), fatty acids, tannins, resin acids, Sulphur and Sulphur compounds, etc. (Ali and Sreekrishnan, 2001; Souza, 2008). The discharge of insufficiently treated wastewater into rivers or other water streams could lead to serious negative effects on the aquatic life, flora and fauna located in the vicinity of such facilities. While on the other hand, the discharge of this wastewater in domestic wastewater treatment systems also requires additional steps for proper compliance with the country's standards. Thereby, development and implementation of effective solutions to ensure effluent organic matter removal before any discharge activities are necessary (Kesalkar et al., 2012). Moreover, in Brazil, pulp and paper industry effluents are not usually destined to generate energy and even in the presence of wastewater treatment facilities, the resulting biogas is generally flared.

In light of the above-mentioned challenges and to more effectively address them, the adoption of more efficient technologies for simultaneous organic matter removal and energy generation seems essential. Anaerobic digestion (AD), the biological degradation of organic matters, results in the production of biogas generally containing methane $(50-75 \%)$, carbon dioxide $(25-50 \%)$, hydrogen (5-10\%), nitrogen (1-2\%), and traces of hydrogen sulfide (Maghanaki et al., 2013) and has been widely adopted worldwide for sewage sludge treatment. However, the dissemination of this technology for industrial effluents faces limitations in terms of anaerobic reactors' configuration and operating conditions to ensure their feasibility for large scale applications. The upflow anaerobic sludge blanket (UASB) reactor, among other types of anaerobic reactors, has been adopted by the pulp and paper industry globally since the 1980's when its main weakness, i.e., hydraulic retention time (HRT), was overcome (Khan et al., 2011; Kamali et al., 2016; Isola et al., 2018). The biogas produced through the AD can be converted into bioenergy by means of combined heat and power systems.

In fact, $A D$ in the pulp and paper industry began in the 1970s with the first system being an anaerobic lagoon type and subsequently, UASB reactors emerged in the 1980s. In the 1990s, real-scale anaerobic treatment predominated the treatment of effluents generated in the pulp mills around the world (Savant et al., 2006). Brazil presents a leading role in the utilization of UASB reactors and is home to the largest park of anaerobic reactors in the world for sewage treatment (Maghanaki et al., 2013). Nevertheless, UASB reactors are yet to be disseminated in the paper and pulp industry in Brazil. This could be ascribed to the fact that there are limited studies on integrated biorefineries in the pulp and paper industry, as well as, on their economic and environmental assessments clearly presenting their advantages.

Notwithstanding, Brazilian biogas market is still in its development phase, but growing steadily. The Brazilian National Policy on Solid Residues (PNRS), approved by Law 12.350/2010 (Brasil, 2010) and planned to be fully enforced by the end of 2022, should further help with the expansion of biogas plants, even those designed for wastewater treatment. The PNRS's goal is to avoid and prevent the generation of solid residues by promoting sustainability, increasing recycling and proper fina disposal while sharing responsibilities with the whole society, namely government, producers, sellers, and consumers (Esparta, 2016). The Brazilian National Electric Energy Agency (ANEEL) only holds the records of electricity-generating biogas plants connected to the national grid. Given the large size of the Brazilian territory, collection of information on the biogas plants not registered at the ANEEL would demand a major effort. In Brazil, there are 22 biogas power plants connected to the national grid. The majority of these plants are installed on agricultural areas processing residues and at landfills (Persson and Baxter, 2015). The ANEEL is also responsible for the regulatory aspects of the electricity sector and has the power to decide and encourage research \& development projects in the main areas of social interest including those related to wider and better use of nonconventional energy resources such as the ones derived from liquid effluents (ANEEL, 2008; MME, 2018a) According to the ANEEL, biomass is considered as one of the main alternatives for diversification of the Brazilian energy matrix, thereby reducing dependence on fossil fuels.

From the economic perspective, the use of clean and low-cost fuels such as the electrical and thermal energy generated from biogas is of significance. In light of that, distributed generation is currently seen as the solution to existing problems while offering benefits including reliability, high power quality, and more environmentally friendly features. Therefore, future electrical power grids tend to be decentralized and to include a large number of small- and medium-sized distributed plants (Ramos et al., 2014). Overall, important systemic aspects, i.e., economic, social, and environmental ones, should be considered for biomass-to-energy projects (Novato and Lacerda, 2017).

The main objective of this work is to develop a conceptual 'systemic' framework for engineering of a biorefinery, based on the data obtained from a study case, coupled to a wastewater treatment plant in a pulp and paper mill. The developed framework includes a UASB reactor for secondary wastewater treatment and subsequently, biogas energy recovery in boilers for thermal power (TP) and electrical power (EP) generation.

\section{Materials and Methods}

\subsection{Case study: an industrial paper mill in the state of São Paulo (Brazil)}

The case study includes a paper mill located in the state of São Paulo, Brazil, which has invested USD 3.4 million in an advanced wastewater treatment system from 2004 to 2014. The paper mill considered in this case study is set for the production of white top line (WTL) or newsprint only. The hourly production capacity of the paper mill, i.e., $12.9 \mathrm{ton} / \mathrm{h}$ WTL or newsprint could be computed according to Equation 1 considering paper grade/weight of $150 \mathrm{~g} / \mathrm{m}^{2}$, velocity of paper machine $(\mathrm{PM})$ of $550 \mathrm{~m} / \mathrm{min}$, and sheet width of $2.6 \mathrm{~m}$. For each ton of WTL or newsprint produced, 30 $\mathrm{m}^{3}$ of water is consumed.

$$
\begin{aligned}
& \text { Production }\left(\frac{K g}{h}\right) \\
& =\frac{\left[\text { velocity of } P M\left(\frac{m}{\mathrm{~min}}\right) \times \text { paper weight }\left(\frac{g}{\mathrm{~m}^{2}}\right) \times \text { sheet width }(\mathrm{m}) \times 60(\mathrm{~min})\right]}{1000}
\end{aligned}
$$

The advanced wastewater treatment facility consists of three different parts. The primary treatment consists in an equalization tank and an effluent 


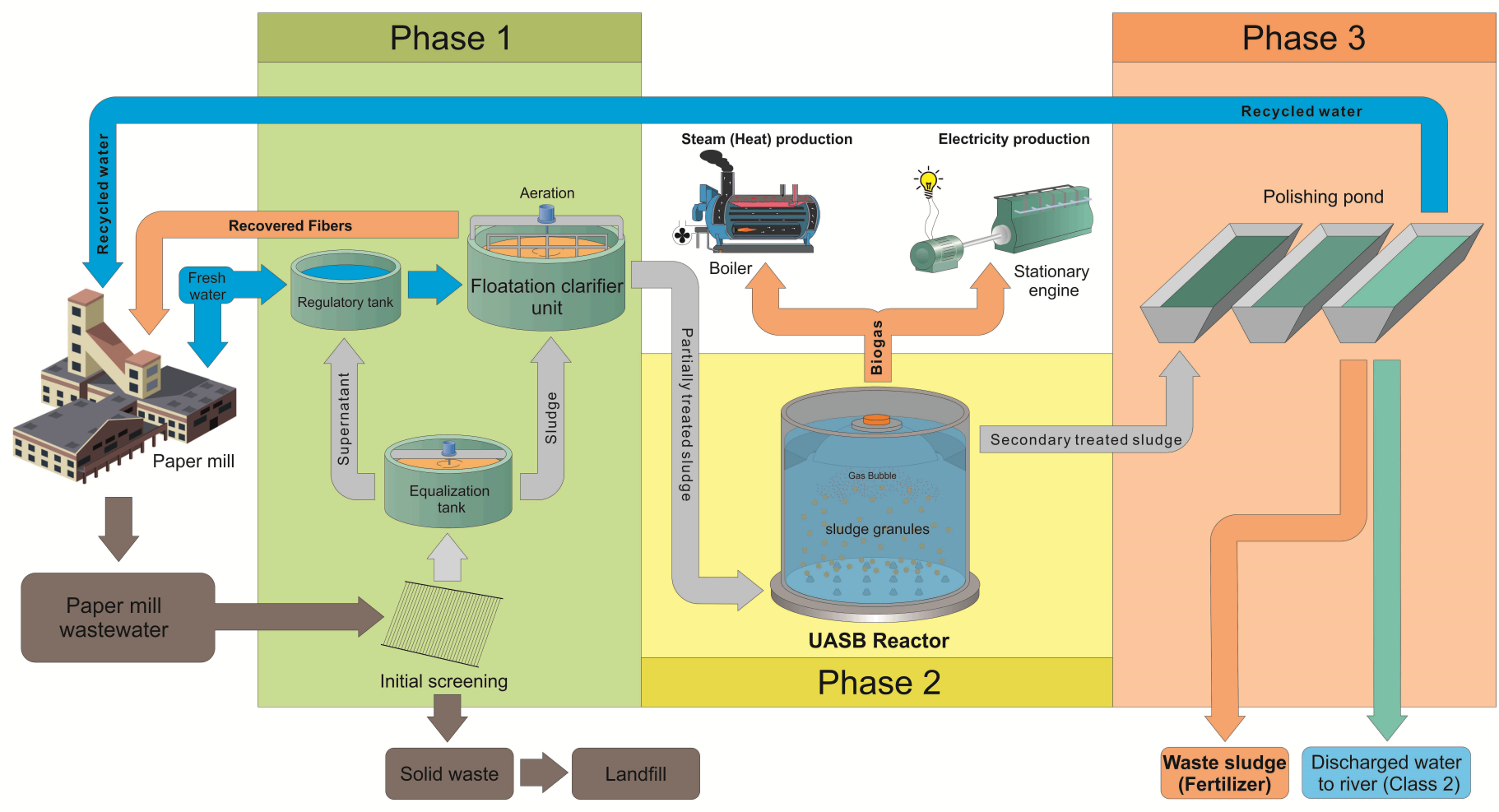

Fig. 1. The biorefinery framework including an advanced wastewater treatment system developed for a paper mill industry located in the state of São Paulo, Brazil.

flotation system. The secondary treatment consists of UASB reactors (UASB 1 and 2). The first UASB reactor was incorporated into the existing effluent treatment system at the mill in 2004. In 2014, a second UASB reactor was incorporated. Finally, the tertiary treatment is performed in an aerobic polishing pond. The advanced wastewater treatment system including different parts/streams involved is presented in Figure 1. More specifically, the first part is a conventional aerobic treatment system including primary settling and sludge digestion after treatment. The second part is a combined AD consisting of two UASB reactors, i.e., the beating heart of the developed biorefinery, where the generated biogas is directed to a boiler (to produce steam for heating) and a stationary engine (for electricity generation). The third part is an additional sludge digestion post-treatment including a polishing pond. At this stage, contaminants are removed in accordance with the environmental regulations, offering the possibility of using the treated effluent as reuse water in the paper and pulp production stage. Furthermore, the UASB reactor bottom sludge could be applied as soil fertilizer or could be further processed by pyrolysis to produce biochar which can be used as soil conditioner (Buller et al., 2014; Elkhalifa, 2019) and activated carbon (Alhashimi, 2017).

The integration of the processes presented here can be classified as a biorefinery. The use of biogas to generate heat and power could contribute to decreased consumption of natural gas (NG) in the plant while reducing the plant`s overall $\mathrm{CO}_{2}$ emissions.

\subsection{Advanced wastewater treatment system: phases and their description}

The energy value of biogas was determined by the average concentration of methane, which has the lower heating value (LHV) of $35.59 \mathrm{MJ} / \mathrm{Nm}^{3}$ (Salomon and Lora, 2009). The primary equipment commonly employed to use biogas as fuel to produce electricity are internal combustion engines, mainly because of the costs of acquisition, operation, and maintenance. The generated biogas (with $70 \%$ of methane) can be readily used as fuel in the generators located in paper mills as most of existing engines are operated on NG. Nevertheless, in order to select an appropriate size of the generator, the following parameters should be considered: i) efficiency of the engine generator; ii) calorific value of biogas; and iii) generation plant working time, and iv) daily availability of biogas in the unit $\left(\mathrm{m}^{3} / \mathrm{d}\right)$. The two routes considered as biogas destination within the biorefinery framework are presented in Figure 1.

\subsection{Biogas production}

The $\mathrm{pH}$ of UASB reactors was measured as 6.7 to 7.8 while the temperature was kept at $30^{\circ} \mathrm{C}$ (mesophilic reactor). Moreover, the sediment residue (SR) was measures at $100 \mathrm{~mL} / \mathrm{L}$. Under such conditions, the organic loading rate (OLR) of the UASB system could be obtained using Equation 2:

$O L R=$ Reactor Net Volume $\left(\frac{m^{3}}{d}\right) \times \operatorname{COD}\left(\frac{\mathrm{kg} C O D}{\mathrm{~m}^{3}}\right)$

Considering $0.3 \mathrm{~m}^{3}$ of methane gas $\left(\mathrm{CH}_{4}\right) / \mathrm{kg}$ organic load removed (Torkian et al., 2003), as well as an annual average COD removal efficiency of $80 \%$ as measured throughout this case study, the volume of biogas generated $(\mathrm{Q})$ could be calculated as follows.

$Q_{C H 4}=0.8 \times O L R\left(\frac{k g C O D}{d}\right) \times 0.3\left(\frac{m^{3}}{k g \text { COD removed }(O L R)}\right)$ 
As the biogas produced herein has an average $\mathrm{CH}_{4}$ content of $70 \%$, biogas production could be obtained by Equation 4 .

$Q_{\text {biogas }}=\frac{Q_{C H 4}}{0.70}$

\subsection{Potential of electricity generation by using biogas-fed stationary engine}

The electricity generation (EG) from a stationary engine fed by biogas can be calculated according to Equation 5 (Lymberopoulos, 2004; Lobato et al., 2012).

$E G=Q_{\text {biogas }} \times L C V_{C H 4} \times C_{m} \times n_{e} \times n_{g} \times F_{c}$

where,

EG - Electricity generation potential $(M J / d)$;

$Q_{\text {biogas }}$ - Amount of biogas $\left(\mathrm{m}^{3} / \mathrm{d}\right)$;

LCV - Lower calorific value of methane $\left(\mathrm{MJ} / \mathrm{m}^{3}\right)$;

$C_{m}$ - Percentage of methane in biogas $(\%)$;

$n_{e}$ - Engine efficiency $(\%)$;

$n_{g}$ - Generator efficiency $(\%)$;

$F_{c}$ - Correction factor due to uncertainties $(\%)$. This factor takes into account the losses in the pipes, mechanical couplings, the presence of other gases not fully quantified, and other factors that lead to losses in the final energy generated.

The values of the parameters are presented in Table 1 .

Table 1.

Values of the parameters required to obtain electricity generation (EG) potential through using a stationary engine fed by biogas.

\begin{tabular}{lcccc}
\hline $\operatorname{LCV}\left(\mathbf{M J} / \mathbf{m}^{\mathbf{3}}\right)$ & $\mathbf{n}_{\mathbf{e}}(\%)$ & $\mathbf{C}_{\mathbf{m}}(\%)$ & $\mathbf{n}_{\mathbf{g}}(\%)$ & $\mathbf{F}_{\mathbf{c}}(\%)$ \\
\hline $\mathbf{3 5 . 5 9}$ & 34 & 70 & 95 & 90 \\
\hline
\end{tabular}

\subsection{Potential of heat generation by using biogas-fed boiler}

The use of biogas for the sole purpose of heat generation is simpler than electricity generation and less complex requirements should be observed.

The total energy produced (EP) per day could be calculated using the following Equation 6.

$E P=Q_{\text {biogas }} \times C_{m} \times L C V_{C H 4}$

where,

EP - Energy produced $(M J / d)$

$Q_{\text {biogas }}$ - Amount of biogas $\left(\mathrm{m}^{3} / d\right)$;

$C_{m}$ - Percentage of methane in biogas (\%);

$L C V$ - Lower calorific value of methane $\left(\mathrm{MJ} / \mathrm{m}^{3}\right)$.

\subsection{Avoided emissions by using biogas}

\subsubsection{Avoided $G H G$ emissions due to electricity generation $\left(A G H G_{E G}\right)$}

The avoided GHG emissions through electricity generation $\left(\mathrm{AGHG}_{\mathrm{EG}}\right)$ by burning the biogas produced in a stationary engine were obtained according to Equation 7. The parameters were based on the data provided by the Brazilian Ministry of Science, Technology, Innovation, and Communication (MCTIC, 2018). For the emission factor attributed to the favorable impact of the electricity generated by using biogas, the average value of the GHG emissions recorded throughout the 2018 was considered (Table S1). The resulting emission factor indicating the reduction in GHG emissions in response to using biogas vs. NG was 0.0786 ton $\mathrm{CO}_{2} \mathrm{eq} / \mathrm{MWh}$
$A G H G_{E G}=0.0786 \times E G \times T$

Eq. (7)

where, EG is the electricity generated converted to MWh and T is the time of operation of the plant during the year $(\mathrm{h})$.

\subsubsection{Avoided $G H G$ emissions due to heat generation $\left(A G H G_{H G}\right)$}

To calculate the avoided GHG emissions due to heat generation $\left(\mathrm{AGHG}_{\mathrm{HG}}\right)$ by suing biogas, it was assumed that the total volume of biogas produced would be burned in the existing boiler as a renewable substitute for the Brazilian NG. Accordingly, the avoided emissions would be the amount of tons $\mathrm{CO}_{2 \mathrm{eq}}$ emitted through using the NG in the boiler multiplied by an emission factor (Eq. 8) (ECOPART, 2009).

$A G H G_{E G}=0.056 \times H G \times T$

where, 0.056 is the emission factor in tons of $\mathrm{CO}_{2 \mathrm{eq}} / \mathrm{GJ}, \mathrm{HG}$ is the heat generated by burning all of the biogas produced in the year 2018, and $\mathrm{T}$ is the time of operation (h) (i.e., 4,350 h).

\subsection{Avoided costs by using biogas}

\subsubsection{Avoided cost due to electricity generation $\left(A C_{E G}\right)$}

When biogas is used for electricity generation, part of the power needed for the paper mill operation could be replaced and an avoided cost could be calculated.

The price of electric power was computed using the report by the Brazilian Electrical Energy Trade Chamber (CCEE, 2018) considering the following specifications; annual data for the Southeast region of Brazil (case study location) throughout the year 2018 for the heavy-demand electricity sector (Table S2). The mean value computed was 74.30 USD/MWh. The avoided cost as a result of electricity generation using biogas was calculated by Equation 9.

$$
A C_{E G}=74.30 \times E G \times T
$$

where, EG is the electricity generation potential converted to MW (see Eq 5, Section 2.4) and $\mathrm{T}$ is the time of operation for the plant throughout the year (h), i.e., 4,350 $\mathrm{h}$ corresponding to the real operation of the advanced wastewater treatment system (i.e., $50 \%$ of its whole capacity) in the study case.

\subsubsection{Avoided costs due to heat generation $\left(A C_{H G}\right)$}

The avoided costs as a result of NG replacement by biogas is calculated by considering the volume of NG replaced according to data from the Mines and Energy Ministry (MME, 2018b). The plant consumes $150 \mathrm{~m}^{3} \mathrm{NG} /$ ton paper produced which is equivalent to $526.5 \mathrm{~m}^{3} \mathrm{NG} / \mathrm{h}$. For such a magnitude of consumption, according to Comgás (a Brazilian gas supplier), the variable cost is $0.38 \mathrm{USD} / \mathrm{m}^{3}$ (Table 3) (Comgás, 2019)

According to the Mines and Energy Ministry, the LHV of the NG consumed is $36.84 \mathrm{MJ} / \mathrm{kg}$, or $27.26 \mathrm{MJ} / \mathrm{m}^{3}$, assuming the stated density of $0.74 \mathrm{~kg} / \mathrm{m}^{3}$ (MME, 2018b). Hence, the avoided costs through using biogas for heat generation $\left(\mathrm{AC}_{\mathrm{HG}}\right)$ were obtained by using Equation 10 .

$A C_{H G}=$ Volumetric $\operatorname{Cost}_{N G} \times \frac{H G \times T}{L H V_{N G}}$

where, HG is the heat generated by biogas, $\mathrm{T}$ is the time of operation and $\mathrm{LHV}_{\mathrm{NG}}$ is the lower heating value of NG (see Supplementary file for more information on emissions and prices).

\subsection{Financial analysis}

Economic and financial analysis could reveal the viability, stability, and profitability indicators of a project under investigation. Balance sheets, assets and resources information, net income and cash flow statements, etc are some of the necessary information required to obtain the abovementioned indicators in order to support decision making processes. Financial analysis focuses on the business profitability and provides 
information to potential investors, while the economic analysis deals with public profitability of the project and is linked to opportunity costs.

In this case study, a financial analysis was performed considering two profitability indicators (a) and (b) for risk assessment along with the classic payback (c) (Blank and Tarkin, 2012).

(a) Profit margin, the ratio of net incomes and revenues (net profits over sales). This measures the percentage of sales incorporating into company's earnings.

(b) Return on assets (ROA) indicating the profitability (relative to the total assets). This is calculated as annual earnings over total assets.

(c) Payback is the period (yr) required to exhaust the original investment.

The analysis was carried out considering the mean paper price in the market (450 USD /ton paper) as well as the following financial parameters:

- UASB Acquisition Cost $=$ USD 3,4 million

- Financing Period $=120$ months $(10 \mathrm{yr})$

- $\quad$ Payment $=$ Main Stream + Interest Rate

- Interest Rate $=$ Financing cost + Bank Spread + Financial Agent

- $\quad$ Spread Interest Rate $=9.25 \% / y r$

- $\quad$ Financing Cost $=$ Long Term Interest Rate $=6.85 \% / y r$

- Bank Spread $=1.40 \% / \mathrm{yr}$

- $\quad$ Financial Agent Spread $=1.00 \% / y r$

- Depreciation Horizon for UASB $=25 \mathrm{yr}$ (financial depreciation rate of 3\%)

- Intangible Assets $=10 \%$ of Acquisition Cost (payment rate in installments fund, on intangible assets of $3 \%$ ).

The financial analysis carried out here did not consider the avoided costs related to biogas energy recovery in feedback loops for the boiler and stationary engine. More information on the calculations are provided in Supplementary file.

\section{Results and Discussion}

\subsection{Technical results}

The present case study was devoted to develop a conceptual 'systemic' biorefinery framework developed for a paper mill located in São Paulo state, Brazil. The elements of this biorefinery included an advanced three-phased wastewater treatment plant to simultaneously treat pulp and paper mill wastewater and produce biogas using $\mathrm{AD}$ (UASB reactors) biogas coupled to energy recovery in boilers for thermal (TP) and electricity generation (EP) (Fig. 1). Other advantageous features of this biorefinery included water and fiber recycling as well as production of agriculture fertilizer as another value-added product. The technical-analytical parameters calculated for the developed biorefinery, i.e., OLR, amount of Methane produced $\left(\mathrm{Q}_{\mathrm{CH} 4}\right)$, amount of biogas produced (Qbiogas), electricity generation (EG), and energy produced (EP) (Table 2).

Table 2.

The analytical-technical parameters calculated for the developed biorefinery in the pulp and paper industry aimed at energy recovery through biogas production (Eqs. 1 to 6).

\begin{tabular}{lll}
\hline Parameter & Value & Unit \\
\hline OLR- Organic loading rate & 12,960 & $\mathrm{kgCOD} / \mathrm{d}$ \\
QCH4- Amount of methane & 3,110 & $\mathrm{~m}^{3} / \mathrm{d}$ \\
Qbiogas-Amount of biogas & 4,443 & $\mathrm{~m}^{3} / \mathrm{d}$ \\
EG- Electricity generation & $32,178.25$ & $\mathrm{MJ} / \mathrm{d}$ \\
EP- Energy produced & 8.94 & $\mathrm{MWh} / \mathrm{d}$ \\
\hline
\end{tabular}

The volume of paper mill wastewater introduced into the primary treatment facility is $9,288 \mathrm{~m}^{3} / \mathrm{d}$ and the volume of effluent transferred to the UASBs reactor is $7,200 \mathrm{~m}^{3} / \mathrm{d}$. The difference of $2,088 \mathrm{~m}^{3} / \mathrm{d}$ is returned to the pulp preparation and paper machine. The measured efficiency of the first phase of the treatment stands at approximately $20 \%$ resulting an effluent with a COD of approximately $1,950 \mathrm{mg} / \mathrm{L}$ (annual mean value, Table 3 ). With an HRT $16 \mathrm{~h}$ in the UASB reactors, the COD is reduced to as low as an annual average value of $295 \mathrm{mg} / \mathrm{L}$ corresponding to an approximate efficiency of $80 \%$ (considering the UASB influent organic load). In another word, a significant reduction in COD was obtained through the USAB-based anaerobic treatment of the wastewater, even at the high OLR of 12,960 kg $\mathrm{COD} / \mathrm{d}$ and short HRT of $16 \mathrm{~h}$ employed.

Table 3.

Chemical organic demand (COD) (mg/L) of the effluents leaving different phases of the advanced wastewater treatment implemented within the developed pulp and paper biorefinery throughout the case study (2018).

\begin{tabular}{|c|c|c|c|c|}
\hline & & Pahse 1 & Phase 2 & Phase 3 \\
\hline Month (2018) & $\begin{array}{l}\text { Pulp and paper } \\
\text { wastewater }\end{array}$ & $\begin{array}{l}\text { Effluent leaving } \\
\text { the flotation } \\
\text { clarifier unit }\end{array}$ & $\begin{array}{l}\text { Effluent } \\
\text { leaving the } \\
\text { UASBs }\end{array}$ & $\begin{array}{c}\text { Effluent } \\
\text { leaving the } \\
\text { poloshing } \\
\text { pond }\end{array}$ \\
\hline January & 2,672 & 2,138 & 321 & 289 \\
\hline February & 3,520 & 2,816 & 422 & 380 \\
\hline March & 2,260 & 1,808 & 271 & 244 \\
\hline May & 2,305 & 1,844 & 277 & 249 \\
\hline June & 2,064 & 1,651 & 248 & 223 \\
\hline July & 2,786 & 2,229 & 334 & 301 \\
\hline August & 2,150 & 1,720 & 258 & 232 \\
\hline September & 2,331 & 1,865 & 280 & 252 \\
\hline October & 2,387 & 1,910 & 286 & 258 \\
\hline November & 2,230 & 1,784 & 268 & 241 \\
\hline December & 2,290 & 1,832 & 275 & 247 \\
\hline
\end{tabular}

During the third phase of treatment (i.e., polishing pond), the COD is further reduced to $265 \mathrm{mg} / \mathrm{L}$ (by $10 \%$ considering the influent of this phase). It should be noted that the Brazilian legislation discharge limit for COD of the final treated wastewater is less than $340 \mathrm{mg} / \mathrm{L}$. Therefore, the discharge water obtained through the present advanced wastewater treatment system meets the national requirement. It should be noted that the secondary sludge (i.e., the sludge produced at the third phase of the treatment) should be concentrated as much as possible to ensure the highest COD and suspended solids removal (Mahmood and Elliott, 2006).

Brazil has two specific laws for the release of industrial and domestic effluents into water bodies, a federal one (MMA, 2011) and a more strict one for the state of São Paulo (CETESB, 1976). The Federal law establishes that the maximum BOD allowed for discharged water is $120 \mathrm{mg} / \mathrm{L}$, and that this limit can only be achieved using treatment systems with a minimum BOD removal efficiency of 60\% (MMA, 2011). Moreover, there is another standard in the state of São Paulo requiring the $\mathrm{BOD}_{5}$ at $20^{\circ} \mathrm{C}$ of discharge water to be lower than $60 \mathrm{mg} / \mathrm{L}$, and this limit could be achieved by wastewater treatment systems capable of reducing the organic load by at least $80 \%$. It should be noted that these standards are used as a basis for licensing new industrial activities and are the reference for Environmental Impact Assessment (EIA) studies (Von Sperling, 2016).

The results of this study were in line with those of Meyer and Edwards (2014) who argued that the COD removal rate in real-scale reactors varies between 30 to $90 \%$ with the highest COD removal rates recorded for the condensate flows from chemical pulp (75 to 90\%) and paper mill effluent (60 to 80\%). The high COD removal efficiency of the developed advanced wastewater treatment system herein could be well attributed to the integration of the high performance UASB reactors with the upstream primary treatment (flotation clarifier unit) and the downstream treatment using the polishing pond. In a study, Zhang et al. (2012) compared five different scenarios for wastewater treatment of pulp and paper industry including primary treatment, anaerobic digestion (UASB), sequential batch reactor treatment and oxidation ditch reactor, anaerobic/anoxic process, and 
membrane technologies. They claimed that the most favorable results could be obtained through integrating these processes.

\subsection{Avoided GHG emissions}

Integration of the processes within a biorefinery framework could lead to the generation of a number of value-added products resulting in an enhanced economic viability of the whole process (Cherubini, 2010). More specifically, energy recovery was maximized in the present study through biogas production from paper and pulp wastewater and its conversion into heat and power as two possible routes. Moreover, the water footprint of the overall system was improved. Nevertheless, to ensure the sustainability of a developed biorefinery, thorough economic and environmental assessments should be performed (Loftus et al., 2015).

The internal combustion engine which was already in use in the paper mill to produce electricity was modified to burn biogas while burning biogas in boilers was also considered to generate steam (heat). From the data obtained on biogas volume produced $\left(\mathrm{Q}_{\text {biogas }}\right)$ and its potential for $\mathrm{EG}$ and $\mathrm{HG}$, the avoided emissions for both alternatives were separately obtained. The emissions avoided through the substitution of NG with biogas for heat generation were considerably higher than the values recorded for biogas conversion into electricity route (Table 4). Considering the emission factor for pulp and paper industry in Brazil, i.e., 0.33 ton $\mathrm{CO}_{2 \mathrm{eq}}$ /ton of pulp and paper (MCTIC, 2017) and the country`s pulp and paper production, i.e., 19.5 and 10.5 millions tons, respectively (IBA, 2017), the emissions of the whole sector could be estimated at $9.9 \times 10^{6}$ ton $\mathrm{CO}_{2 \mathrm{eq}} / \mathrm{yr}$. Considering the avoided emissions obtained per ton of paper produced in the present study and the paper production of 10.5 millions tons, the substitution of NG by biogas could avoid more than $1.06 \times 10^{5}$ ton $\mathrm{CO}_{2 \mathrm{eq}} / \mathrm{yr}$.

Table 4.

Avoided emissions and costs through replacing natural gas with biogas for heat and electricity generation.

\begin{tabular}{lcc}
\hline Parameter & $\begin{array}{c}\text { Electricity generation } \\
(\mathbf{E G})\end{array}$ & $\begin{array}{c}\text { Heat generation } \\
(\mathbf{H G})\end{array}$ \\
\hline Avoided emissions $\left(\mathbf{t C O} \mathbf{C e q}_{2 \mathrm{yr}} / \mathbf{r}\right)$ & 127.0 & $1,125.5$ \\
Avoided costs (Million USD/yr) & 2.89 & 0.28 \\
\hline
\end{tabular}

\subsection{Avoided costs and financial results}

From the economic perspective, although both alternative routes result in avoiding the use of conventional energy sources (i.e., grid electricity and NG), the avoided costs attributed to the replacement of electrical energy from biogas are ten-fold higher than the costs avoided through replacing NG by biogas. It should be noted that when computing the avoided costs, the country's energy matrix and the seasonality of energy supply (depending on rainfall regime) as well as the fact that the country relies on thermoelectric energy to fulfill national needs in the dry seasons of the year were also considered. Thermoelectric energy is more expensive than hydroelectric energy and its cost is reflected in the mean market energy price considered here (dos Santos et al., 2018).

Based on the financial analysis and considering only the investment on the two UASB reactors with $50 \%$ working capacity, the payback on these units for the investigated paper mill plant in full time operation would be $6.4 \mathrm{yr}$ while the ROA of the whole plant following UASB reactors acquisition would be $14 \%$. The profit margin could be estimated at 35\% taking into account both the paper mill original investment and the costs associate with the UASB reactors acquisition. The investment on the UASB reactors accounts for only $6.8 \%$ of the annual sales while contributes $19.8 \%$ of the operational profit with the depreciation period of $25 \mathrm{yr}$. This shows that the investment on the UASB reactors would not impose a significant financial burden. It should be highlighted that the average ROA for Brazilian pulp and paper mill industry stands at $18 \%$ while the average profit margin is $38 \%$. Accordingly, the results of the present case study reveal that the investment required for the implementation of UASB reactors in the paper mill industry would be minimal while it could bring along significant benefits through avoiding GHG emission and by energy recovery.

\section{Conclusions}

Paper industry generates a large amount of liquid and solid effluents originating from the production process involved. These waste streams could be valorized by generating a range of biomaterials and bioenergy carriers. The findings of the present study clearly indicated that the adoption of UASB reactors by the paper mill industries could assist with effectively addressing environmental concerns faced by the industry while could simultaneously contribute to the energy matrix transition in favor of more renewable energy resources.

In addition, the financial analysis conducted herein proved that considering the investment in UASB reactors constitutes a minor fraction of the whole paper mill investment. Moreover, this investment in UASB reactors even when the reactors are used using at half of their operational capacity, would be expected to be returned with a short period of time 6.4 yr) with a high ORI. Moreover, through the implementation of the developed UASB reactor-based biorefinery, the Brazilian paper industry as a whole could avoid $1.06 \times 10^{5}$ ton $\mathrm{CO}_{2 \mathrm{eq}} / \mathrm{yr}$, contributing to the decarbonization of the country`s economy.

Given the promising features of the presented biorefinery in terms of the production of various bioenergy carriers and biomaterials, regulations and policies at various levels of the government must be adapted to facilitate the implementation of the technology while take into consideration its social, environmental, and economic impacts.

\section{Acknowledgements}

The authors would like to acknowledge the financial support from the Brazilian Science and Research Foundation - CNPq (132627/2016-7). This study was financed in part by the Coordination for the Improvement of Higher Education Personnel (CAPES, Brazil) - Finance code 001. T.F.C would like to acknowledges the financial support from the São Paulo Research Foundation - FAPESP (2011/19817-1, 2018/05999-0 and 2018/14938-4).

\section{References}

[1] Alhashimi, H.A., Aktas, C.B., 2017. Life cycle environmental and economic performance of biochar compared with activated carbon: a meta-analysis. Resour. Conserv. Recycl. 118, 13-26.

[2] Ali, M., Sreekrishnan, T.R., 2001. Aquatic toxicity from pulp and paper mill effluents: a review. Adv. Environ. Res. 5(2), 175-196.

[3] ANEEL., 2008. Atlas de Energia Elétrica do Brasil. 3rd edition, Brasília.

[4] Bayr, S., Kaparaju, P., Rintala, J., 2013. Screening pretreatment methods to enhance thermophilic anaerobic digestion of pulp and paper mill wastewater treatment secondary sludge. Chem. Eng. J. 223, 479-486

[5] Berni, M., Dorileo, I., Nathia, G., Forster-Carneiro, T., Lachos, D., Santos, B.G., 2014. Anaerobic digestion and biogas production: combine effluent treatment with energy generation in UASB reactor as biorefinery annex. Int. J. Chem. Eng. 2014, 8 .

[6] Blank, L., Tarkin, A., 2012. Engineering Economy, $7^{\text {th }}$ ed. McGraw Hill, New York.

[7] Brasil, 2010. Lei $n^{\circ}$ 12.305, de 2 de agosto de 2010 .

[8] Buller, L.S., Bergier, I., Ortega, E., Moraes, A., Bayma-Silva, G., Zanetti, M.R., 2014. Soil improvement and mitigation of greenhouse gas emissions for integrated crop-livestock systems: case study assessment in the Pantanal savanna highland, Brazil. Agric. Syst. 137, 206-219.

[9] CCEE., 2018. Prices in XLS format

[10] CETESB., 1976. Decreto n. 8.468, de 8 de setembro de 1976.

[11] Cherubini, F., 2010. The biorefinery concept: using biomass instead of oil for producing energy and chemicals. Energy Convers. Manage. 51(7), 1412-1421

[12] Comgás, 2019. Tarifas do gás natural canalizado. 
[13] Correia, N.M., Rezende, P., 2002. Manejo integrado de plantas daninhas na cultura da soja. lavras: editora UFLA.

[14] dos Santos, I.F.S., Vieira, N.D.B., de Nóbrega, L.G.B., Barros, R.M., Tiago Filho, G.L., 2018. Assessment of potential biogas production from multiple organic wastes in Brazil: impact on energy generation, use, and emissions abatement. Resour. Conserv. Recycl. 131, 54-63.

[15] ECOPART., 2009. Relatório inventário de gases de efeito estufa fibria unidades operacionais jacaréi- aracruz-guaíba florestal-industriallogística inventário de carbono 2009-Ano base 2008.

[16] Elkhalifa, S., Al-Ansari, T., Mackey, H.R., McKay, G., 2019. Food waste to biochars through pyrolysis: a review. Resour. Conserv. Recycl. 144, 310-320.

[17] Esparta, A.R.J., 2016. Mapping report part 2-biogas and biomethane, low carbon business action in Brazil service contract for European union external actions.

[18] Fiore, S., Ruffino, B., Campo, G., Roati, C., Zanetti, M.C., 2016. Scaleup evaluation of the anaerobic digestion of food-processing industrial wastes. Renewable Energy. 96, 949-959.

[19] Foelkel, C., 2010. Resíduos sólidos industriais do processo de fabricação de celulose e papel de eucalipto. Parte 03: Lodos \& Lodos.

[20] IBÁ., 2017. Relatório Anual 2017.

[21] Kamali, M., Gameiro, T., Costa, M.E.V., Capela, I., 2016. Anaerobic digestion of pulp and paper mill wastes-an overview of the developments and improvement opportunities. Chem. Eng. J. 298, 162182.

[22] Kesalkar, V., Khedikar, I.P., Sudame, A.M., 2012. Physico-chemical characteristics of wastewater from paper industry. Int. J. Eng. Res. Appl. 2(4), 137-143.

[23] Krakat, N., Westphal, A., Schmidt, S., Scherer, P., 2010. Anaerobic digestion of renewable biomass: thermophilic temperature governs methanogen population dynamics. Appl. Environ. Microbiol. 76(6), 1842-1850.

[24] Lobato, L.C.S., Chernicharo, C.A.L., Souza, C.L., 2012. Estimates of methane loss and energy recovery potential in anaerobic reactors treating domestic wastewater. Water Sci. Technol. 66(12), 2745-2753.

[25] Loftus, P.J., Cohen, A.M., Long, J.C., Jenkins, J.D., 2015. A critical review of global decarbonization scenarios: what do they tell us about feasibility?. wiley interdiscip. Rev. Clim. Change. 6(1), 93-112.

[26] Lymberopoulos, N., 2004. Microturbines and their application in bioenergy.

[27] Maghanaki, M.M., Ghobadian, B., Najafi, G., Galogah, R.J., 2013. Potential of biogas production in Iran. Renew. Sust. Energy Rev. 28, $702-714$.

[28] Mahmood, T., Elliott, A., 2006. A review of secondary sludge reduction technologies for the pulp and paper industry. Water Res. 40(11), 20932112.
[29] MCTIC., 2017. Modelagem setorial de opções de baixo carbono para o setor de papel e celulose.

[30] MCTIC., 2018. Arquivos dos fatores médios de emissão de $\mathrm{CO}_{2}$ grid mês/ano.

[31] Meyer, T., Edwards, E.A., 2014. Anaerobic digestion of pulp and paper mill wastewater and sludge. Water Res. 65, 321-349.

[32] MMA., 2005. Resolução CONAMA n³57, de 17 de março de 2005.

[33] MMA., 2011. Resolução no 430, de 13 de maio de 2011.

[34] MME., 2018a. RenovaBio.

[35] MME., 2018b. Brazilian energy balance-2018.

[36] Novato, M., Lacerda, M.I., 2017. RenovaBio-towards a new national biofuel policy and a truly sustainable world. Innovative Energy Res. 6, 2.

[37] Persson, T., Baxter, D., 2015. IEA bioenergy task 37-country reports summary 2014

[38] Ramos, A.C.L., Calixto, W.P., Alves, A.J., Domingues, E.G., de Oliveira, S.B., Coelho, S.T., 2014. Proposal of technical and commercial arrangements for distributed generation from the use of biogas in a food industry. Int. Conf. Renew. Energies power quality. Cordoba, Spain. 12.

[39] Salomon, K.R., Lora, E.E.S., 2009. Estimate of the electric energy generating potential for different sources of biogas in Brazil. Biomass Bioenergy. 33(9), 1101-1107.

[40] Savant, D.V., Abdul-Rahman, R., Ranade, D.R., 2006. Anaerobic degradation of adsorbable organic halides (AOX) from pulp and paper industry wastewater. Bioresour. Technol. 97(9), 1092-1104.

[41] Souza, A., 2008. Guia técnico ambiental da indústria de papel e celulose. São Paulo: CETESB.

[42] Torkian, A., Eqbali, A., Hashemian, S.J., 2003. The effect of organic loading rate on the performance of UASB reactor treating slaughterhouse effluent. Resour. Conserv. Recycl. 40(1), 1-11.

[43] von Sperling, M., 2016. Urban wastewater treatment in Brazil. InterAm. Dev. Bank.

[44] Welfle, A., 2017. Balancing growing global bioenergy resource demands-Brazil's biomass potential and the availability of resource for trade. Biomass Bioenergy. 105, 83-95.

[45] Whitman, W., Bowen, T., Boone, D., Balows, A., Truper, H., Dworkin, M., Harder, W., Schleifer, K., 1992. The methanogenic bacteria, in: Balows, A., Trüper, H.G., Dworkin, M., Harder, W., Schleifer, K.H. (Eds), The Prokaryotes. A Handbook on the Biology of Bacteria: Ecophysiology, Isolation, Identification, Applications, 2nd ed., New York: Springer-Verlag. 1, 719-767.

[46] Zhang, C., Chen, J., Wen, Z., 2012. Alternative policy assessment for water pollution control in China's pulp and paper industry. Resour. Conserv. Recycl. 66, 15-26. 


\section{Supplementary file}

Table S1.

Emission factors attributed to the favorable impact of the electricity generated by using biogas throughout the year 2018 .

\begin{tabular}{|c|c|c|c|c|c|c|c|c|c|c|c|c|}
\hline 2017 & & & & & & & & & & & & \\
\hline December & January & February & March & April & May & June & July & August & September & October & November & December \\
\hline 0.0892 & 0.0640 & 0.0608 & 0.0635 & 0.0523 & 0.0607 & 0.0915 & 0.1076 & 0.1181 & 0.1182 & 0.0802 & 0.0366 & --- \\
\hline
\end{tabular}

Source: Brazilian Science, Technology, Innovation and Communication Ministry (MCTIC, 2018).

Table S2.

The price of electric power considering the following specifications; annual data for the Southeast region of Brazil (case study location) throughout 2018 for the heavy demand electricity sector.

\begin{tabular}{|c|c|c|c|c|c|c|c|c|c|}
\hline \multirow{2}{*}{ Month } & \multirow{2}{*}{ Week } & \multicolumn{3}{|c|}{ Price of electric power (USD/MWh) } & \multirow{2}{*}{ Month } & \multirow{2}{*}{ Week } & \multicolumn{3}{|c|}{ Price of electric power (USD/MWh) } \\
\hline & & Heavy & Medium & Light & & & Heavy & Medium & Light \\
\hline 1 & 1 & 50.26 & 50.26 & 49.14 & 7 & 1 & 128.22 & 128.22 & 128.22 \\
\hline 1 & 2 & 45.29 & 45.29 & 44.04 & 7 & 2 & 128.22 & 128.22 & 128.22 \\
\hline 1 & 3 & 41.98 & 41.98 & 40.27 & 7 & 3 & 128.22 & 128.22 & 128.22 \\
\hline 1 & 4 & 50.15 & 50.15 & 46.85 & 7 & 4 & 128.22 & 128.22 & 128.22 \\
\hline 2 & 1 & 45.64 & 45.64 & 42.30 & 8 & 1 & 128.22 & 128.22 & 128.22 \\
\hline 2 & 2 & 46.56 & 46.56 & 43.74 & 8 & 2 & 128.22 & 128.22 & 128.22 \\
\hline 2 & 3 & 43.91 & 43.91 & 42.41 & 8 & 3 & 128.22 & 128.22 & 128.22 \\
\hline 2 & 4 & 54.27 & 54.27 & 52.13 & 8 & 4 & 128.22 & 128.22 & 128.22 \\
\hline 3 & 1 & 52.01 & 52.01 & 49.96 & 8 & 5 & 128.22 & 128.22 & 128.22 \\
\hline 3 & 2 & 57.25 & 57.25 & 55.60 & 9 & 1 & 125.11 & 125.11 & 121.21 \\
\hline 3 & 3 & 60.67 & 60.67 & 58.56 & 9 & 2 & 127.95 & 127.95 & 122.46 \\
\hline 3 & 4 & 56.31 & 56.31 & 54.65 & 9 & 3 & 127.02 & 127.02 & 120.91 \\
\hline 3 & 5 & 59.08 & 59.08 & 56.61 & 9 & 4 & 113.43 & 113.43 & 109.91 \\
\hline 4 & 1 & 10.19 & 10.19 & 10.19 & 10 & 1 & 98.90 & 98.90 & 96.66 \\
\hline 4 & 2 & 22.24 & 22.24 & 20.29 & 10 & 2 & 83.25 & 83.25 & 81.80 \\
\hline 4 & 3 & 31.81 & 31.81 & 29.99 & 10 & 3 & 69.79 & 69.79 & 66.52 \\
\hline 4 & 4 & 35.21 & 35.21 & 33.26 & 10 & 4 & 59.08 & 59.08 & 56.94 \\
\hline 5 & 1 & 56.51 & 56.47 & 53.17 & 11 & 1 & 36.46 & 36.46 & 35.72 \\
\hline 5 & 2 & 79.40 & 79.40 & 74.60 & 11 & 2 & 38.46 & 38.46 & 37.35 \\
\hline 5 & 3 & 84.72 & 84.72 & 79.60 & 11 & 3 & 30.94 & 30.94 & 30.28 \\
\hline 5 & 4 & 88.43 & 88.43 & 83.10 & 11 & 4 & 30.64 & 30.64 & 29.57 \\
\hline 6 & 1 & 106.34 & 106.34 & 96.60 & 11 & 5 & 25.81 & 25.81 & 25.12 \\
\hline 6 & 2 & 116.13 & 116.13 & 104.55 & 12 & 1 & 15.08 & 15.08 & 14.81 \\
\hline 6 & 3 & 122.41 & 121.83 & 116.21 & 12 & 2 & 16.86 & 16.86 & 16.66 \\
\hline 6 & 4 & 123.31 & 123.31 & 117.66 & 12 & 3 & 20.35 & 20.35 & 19.63 \\
\hline 6 & 5 & 128.22 & 128.22 & 128.22 & 12 & 4 & 22.37 & 22.37 & 21.82 \\
\hline
\end{tabular}

Source: Brazilian Electrical Energy Trade Chamber (CCEE, 2018). 
Table S3.

Cost of natural gas for the industrial sector in Brazil, proportional to the consumption volume per month

\begin{tabular}{lll}
\hline Prices for industrial sector & Prices (excluding commercial national tax) ${ }^{\mathbf{A}}$ \\
\hline Class & Volume $\mathbf{~ m}^{3} / \mathbf{m o n t h}$ & Variable $-\mathbf{U S D} / \mathbf{m}^{3}$ \\
\hline 1 & Until $50.000,00 \mathrm{~m}^{3}$ & 0.540 \\
2 & $50.000,01$ to $300.000,00 \mathrm{~m}^{3}$ & 0.380 \\
3 & $300.000,01$ to $500.000,00 \mathrm{~m}^{3}$ & 0.362 \\
4 & $500.000,01$ to $1.000 .000,00 \mathrm{~m}^{3}$ & 0.358 \\
5 & $1.000 .000,01$ to $2.000 .000,00 \mathrm{~m}^{3}$ & 0.352 \\
6 & $>2.000 .000,00 \mathrm{~m}^{3}$ & 0.346 \\
\hline
\end{tabular}

A Brazilian commercial tax acronym is ICMS, which is charged on all goods and services that circulate. Source: COMGÁS (2019).

Financial analysis supplementary information

\section{Financial Resources}

Full Paper Mill Equipment $=$ USD 50,155,200.00

UASB Acquisition Cost $=$ USD 3,400,000.00

Financing Time $=10 \mathrm{yr}$

Payment $=$ Main stream + Interest rate

Interest Rate $=$ Financing Cost + BNDES Spread + Financial Agent Spread

Interest rate $=9.25 \%$ a. a.

Financing Cost $=$ Long Term Interest Rate $($ LTIR $)=6.85 \%$ a. .

BNDES Spread $=1.40 \%$ a. .

Financial Agent Spread = $1.00 \%$ a.a.

Payment $($ main stream $)=$ USD 340,000.00/yr

Payment (interest) $=$ USD 31,450.00/yr

\section{Depreciation fund - on Permanent Assets}

Rate $=3 \%$ a a (Brazilian usual rate)

Permanent Assets = USD 3,400,000.00

Depreciation Period for UASB $=25 \mathrm{yr}$

Depreciation Fund $=$ USD 4,080.00/yr

\section{Payment in installments fund - on Intangible Assets}

Rate $=3 \%$ a.a (Authors assumption)

Intangible Assets $=10 \%$ of acquisition cost (Authors assumption)

Intangible Assets = USD 340,000.00

Payment in installments fund $=$ USD 10,200.00/yr 